\title{
TOWARD IMPROVED HOUSING OPPORTUNITIES: A NEW DIRECTION FOR ZONING LAW
}

The problems arising from the present state of the law applicable to land development in American suburbs by now are familiar. It is a commonplace to observe that Euclidean zoning's static approach was doomed to disappoint in a dynamic world. The poverty of the conventional "solution"-resort to the amendment processhas likewise become clear with its abuse in the service of discriminatory and exclusionary motives. The indifference of suburban zoning authorities to regional interests is also notorious. And, tragically, the desperate shortage of decent low- and moderate-income housing presents a problem so familiar that concern, if ever it existed, has long since turned to apathy.

In combination, however, these difficulties and problems have defied conventional, legal solution. Certainly the courts have been illequipped to unravel the snarl. And legislative attempts have largely been unimaginative and incomplete.

This Comment proposes a direct confrontation with, and an attempt to resolve, all of these problems. The weapons suggested-the planned unit development and the imposition of quotas-are not novel, and perhaps the thrust will strike many as too simple. In its favor, however, must be the fact that it might work where more sophisticated approaches have failed.

Accordingly, it is recommended that state legislatures require local communities to establish two-part development quotas. Communities should be called upon to determine how much growth they may reasonably be expected to absorb over a five-year period, and how much of the over-all growth would constitute their fair share of regional needs for low- and moderate-income housing. To make possible satisfaction of the latter quota, communities should be expected to require that all developments of a certain size allocate an appropriate percentage of their dwelling units to low- and moderate-income housing. A state reviewing agency should be created with broad relief-granting powers, so as to assure that local communities do not neglect their responsibilities.

\section{Elements of tere Problem}

Prior to closer scrutiny of this Comment's recommendations, a further examination of the problem it seeks to resolve is in order. We shall consider first this country's housing crisis, and then shall review the state of contemporary zoning law-the fallacy of end-state zoning, the ease with which amendment procedures lend themselves to illegiti- 
mate purposes, and the disregard of regional needs. Finally, this portion of the Comment will discuss the inadequacy of judicial handling of these difficulties, for this is truly an area where institutions not part of a solution have become part of the problem.

\section{A. Housing in America}

In 1949 Congress recognized the problem of an inadequate housing supply; ${ }^{1}$ there is no doubt that lack of adequate housing is still a serious national ${ }^{2}$ problem: The Supreme Court has recognized the pressing importance of housing, ${ }^{3}$ and numerous executive studies have concluded that better housing will be crucial to the solution of urban problems. ${ }^{4}$ Yet despite all the studies and recommendations, little of substance has been accomplished to alleviate the problem of inadequate housing for the poor. ${ }^{5}$

The realization has grown in recent years that public housing is not a complete answer. ${ }^{6}$ It has been attacked for its cost, mammoth size, ineffective management, institutional design, short supply, and discriminatory site-selection process. ${ }^{7}$

Relying upon private large-scale development, with governmental assistance, to provide low- and moderate-income housing as a complement to public housing is consistent with our tradition of leaving landuse decisions to the market place and turning to the government only to adjust imperfections. ${ }^{8}$ If private construction of low- and moderateincome housing works, in all likelihood it will not serve the really poor. ${ }^{9}$

I See Housing Act of 1949 § 2, 42 U.S.C. § 1441 (1970); accord, Department of Housing and Urban Development Act of 1968 \$§ 1-10, 42 U.S.C. $\S \S 3531-37$ (1970). See also Fair Housing Act of $1968 \$ 8$ 801-901, 42 U.S.C. \$\$ 3601-31 (1970) (making illegal discrimination in the sale, rental, or financing of housing).

2 See, e.g., Johnston, Developments in Land-Use Control, 45 Notre DaAre Law. 399, 408-13 (1970).

8 See Hunter v. Erickson, 393 U.S. 385 (1969): Jones v. Alfred H. Mayer Co., 392 U.S. 409 (1968); Reitman v. Mulkey, 387 U.S. 369 (1967); Shelley v. Kraemer, 334 U.S. 1 (1948); Block v. Hirsh, 256 U.S. 135 (1921); Buchanan v. Warley, 245 U.S. 60 (1917). But see Lindsey v. Normet, 405 U.S. 56 (1972).

4 See Nationat Advisory Comm's on Civir Disorders, Report 257 (1968) [hereinafter cited as KERNER REPORT]; U.S. PRESIDENT'S COMNM'N ON URBAN HOUSING, A DECENT HONTE (1968) [hereinafter cited as KAISER REPORT].

5 See National Commi's on Urban Problears, Bumding the Amertcan City, H.R. Doc. No. 91-34, 91st. Cong., 1st Sess, 13-16, 153-54 (1969) [hereinafter cited as DovgLas REPORT]; KERNER REPORT, supra note 4, at 259-60; Rouse \& Wehbring, Housing as a National Priority, 39 Geo. WASE. L. ReV. 674 (1971).

- See, e.g., Breckenfeld, Housing Subsidies Are a Grand Delusion, ForTuNE, Feb. 1972, at 136. See also N.Y. Times, Feb. 20, 1972, at 1, col. 5.

7 KERNER REPORT, supra note 4, at 260; Ledbetter, Public Housing-A Social Experiment Seeks Acceptance, 32 LAw \& ContenTP. ProB. 490 (1967). The most serious criticism has been leveled at site selection: Iocal authorities, frequently influenced by racial motives, have tended to place public housing projects in or near ghetto areas. See, e.g., Kennedy Park Homes Ass'n v. City of Lackawanna, 436 F.2d 108 (2d Cir. 1970), cert. denied, 401 U.S. 1010 (1971).

8 See J. Delafons, Land-Use Controis in the United States 7 (2d ed. 1969). See also Klaman, Public/Private Approaches to, Urban Mortgage and Housing Problems, 32 LAW \& ConteMrP. ProB. 250 (1967).

${ }^{9}$ See Genung, Public Housing-Success or Failure?, 39 Geo. WaSH. L. REv. 734 
In this situation, public housing is perhaps the only answer, but there is no doubt that private programs will alleviate pressures on public housing programs. ${ }^{10}$

What must not be lost sight of, however, is that the decisions of private developers or of federal or state agencies are not sufficient. The last word belongs, in practice, to the local community, and exclusionary zoning techniques (of which, more will be said shortly) can easily scuttle desirable projects. This Comment urges that future plans for improved low-income-housing placement come directly to grips with this crucial factor.

\section{B. Zoning}

Zoning law has served, perhaps more than any other factor, to aggravate the housing crisis. As originally conceived, it did not allow for flexible development. This failing found remedy with the exploitation of the amendment process-a remedy, however, as bad as or worse than the disease itself, from the standpoint of those who feel low- and moderate-income housing should have a place in suburban settings. Further adding to the difficulty is the fragmentary approach necessarily entailed by present-day land-use decisionary structures: the absence of a body responsible for promoting regional needs on a basis evenhanded with respect to the region's smaller-community interests, makes understandable the apprehensions suburban planners might feel about taking more than their "share" of low-income residents.

\section{Flexibility}

A brief examination of Euclidean zoning will show that its theory is inconsistent with reality, in that it provides townships with neither the flexibility to deal effectively and sensitively with developers on a case-by-case basis nor the discretion to respond adequately to changing circumstances and preferences.

Suburban zoning in the United States is for the most part based on the Standard State Zoning Enabling Act (SZEA), ${ }^{11}$ ordaining that all land be divided into districts according to use and that within each district the regulations be uniform. ${ }^{12}$ Such districts reflect a built-in resistance to new design and change, since they are established with reference to the state of development at the time of the zoning plan's adoption. New development must be at least similar to existing uses. Since the dominant, and highest, use in suburban zoning is the singlefamily detached dwelling, ${ }^{13}$ few developers have sought to build any-

(1971); Roisman, The Right to Public Housing, 39 Gro. WaSH. L. REv. 691 (1971). See generally KATSER REPORT, supra note 4.

10 See Ledbetter, suspra note 7, at 527.

11 Standard State Zoning Enabling Act (U.S. Dep't of Commerce, rev. ed. 1926). See generally 1 R. ANDERSON, AMERICAN LAW OF ZONING § 3.11 (1968).

12 SZEA $\S 2$; see R. ANDERSON, supra note 11 , $\S 3.13,8.02$.

13 "Promotion of the single-family home . . . is deemed good public policy in Amer- 
thing else-producing the "cookie-cutter" pattern of urban sprawl. ${ }^{14}$

Municipalities and developers, planners and potential homeowners, have of late grown dissatisfied with conventional, single-familydetached, lot-by-lot subdivisions and have sought more flexible and imaginative approaches to land development. ${ }^{15}$ The answer, frequently, has been planned unit development-both a new design technique and a new method of local land-use control.

Regulations for a planned unit development (PUD), unlike conventional zoning, do not apply to individual lots but pertain rather to the entire development area. The approach calls for a substantial amount of administrative discretion and does away with the concept of sharply segregating land uses. ${ }^{16}$ Grouping dwelling units, especially townhouses and apartments, into clusters is a more efficient use of land which both frees land for common open space and permits the developer to build at higher densities without overcrowding. ${ }^{17}$ Housing costs can be reduced, since streets, pavements, and networks of utilities can be shorter..$^{18}$ In addition to the predictable amenities-common open space and recreational areas-PUDs often include non-residential uses, such as shopping and employment centers. ${ }^{19}$

As a regulatory device, the PUD system recognizes that most homebuilding today is done on a large scale by corporate developers ${ }^{20}$ and attempts to strike a balance between the developer's desire to vary

ica." Bettman, Constitutionality of Zoning, 37 HARv. L. REv. 834, 839-40 (1924). Cf. R. Babcock, The Zonng Ganie 127 (1966).

14 See generally F. Bosselman, ALternatives to Urban Sprawl: Legat Gumeline FOR GovernMENTIAI Action (National Comm'n on Urban Problems Research Report No. 15, 1968); Gorlick, Control of Urban Sprawl, California Style, 2 URBan LAw. 95 (1970).

15 See Urban Land Institute [ULI], The Pros and Cons of Ciuster Housing (1969) [hereinafter cited as CIUSTer Housing]; ULI, TECr. BuLl. No. 62, New Zoning Landmariss in Planned Unit Developments (1968); ULI, Tech. BuLL. No. 61, Apartacent Comaronities-Tye NeXI BIg Market (1968); ULI, Tech. BULI. No. 57, Open Space Communities In the Market Piace (1966); ULI, Tech. Bull. No. 52, Legal Aspects of Planned Unt Resmentiat Deveropament (1965) [hereinafter cited as Legal Aspects]; ULI, TeCh. BuLx. No. 50, The Homes Association Handiook (1964); ULI, TeCH. BULt. No. 47, Innovations vs Traditions in Comanunity DeveiopMIENT (1963) [hereinafter cited as InNovatrons]; ULI, Tecr. Butr. No. 40, NEw Approaches to Residential Land Developanent (1961); W. Whyte, Cluster DevelopMOENT (1964); Goldston \& Scheuer, Zoning of Planned Residential Developments, 73 HARv. L. REV. 241 (1959). (1965).

16 See generally Symposium-Planned Unit Development, 114 U. PA. L. REv. 3

17 Cluster housing has been defined as "the elimination of arbitrary lot sizes and the utilization of a minimum of ten percent of the land for common area amenities." CrUSTER Housng, supra note 15 , at 6 .

I8 See, e.g., Innovatrons, supra note 15, at 24-26, 93-95; FHA, Land Puanning Bull. No. 6, Planned-Unit Development with a Homes Association 3 (1963). But see CLUSTER HodsIng, supra note 15, at 19-23, 24; Krasnowiecki, Planned Unit Development: A Challenge to Established Theory and Practice of Land Use Control, 114 U. PA. L. REv. 47, 50-52 (1965).

${ }^{19} \mathrm{M}$. Rivkin, Planned Unit Development: Its Significance for New Communities, Nov. 3-6, 1971 (paper prepared for the American Institute of Architects, New Communities Conferences).

20 See, e.g., Hankè, Planned Unit Development and Land Use Intensity, 114 U. PA. L. Rev. 15, 15-17 (1965). 
uses within a single tract and the community's desires to see quality development and to feel it can rely on what the developer has promised. ${ }^{21}$ Generally, the developer must convince the local governing body that his plan would serve the community's best interest. ${ }^{22}$ The developer, the local legislators, and the planning commission work together; the plan can be modified at the authorities' request. ${ }^{23}$ After final approval, the administrative agency has considerable discretion, even to the extent of permitting certain alterations. ${ }^{24}$

In short, the PUD technique allows a community to exercise more refined, particularized control over larger, more sophisticated development. What is often overlooked, however, is its tremendous potential to provide housing for low- and moderate-income families. ${ }^{25}$ This Comment urges that that potential be exploited.

\section{Amendments Discretionary and Discriminatory}

Early advocates of zoning believed that development patterns could be predetermined, ${ }^{26}$ and therefore saw no need to provide a role for discretion. ${ }^{27}$ The SZEA provides that "regulations shall be made in accordance with a comprehensive plan"28 - a plan prepared by extrapolating from the existing uses of land, the township's appearance twenty or thirty years in the future. ${ }^{29}$ This approach to land-use controls has been characterized as "end-state" zoning, because it attempts to ordain future conditions without admitting of the possibility that changing circumstances may necessitate different goals, and because it neglects to detail intermediate stages or to provide tools to achieve the desired or contemplated end-state. ${ }^{30}$ This is in accord, of course, with the conventional wisdom of free-enterprise economics: the community does not (and, it was thought, should not) make development decisions. Economic initiative follows control of the means of production;

21 See, e.g., D. Mandelker, Controlitng Planned Resmential Development (1966); Krasnowiecki, supra note 18, at 78-97; LEGAL AsPECTs, supra note 15.

22 See Babcock, McBride \& Krasnowiecki, A Model State Enabling Act with Commentary for Planned Unit Residential Development, in LEGAL Aspecrs, supra note 15, at 76-77 [reprinted with slight modifications in 114 U. PA. L. REv. 140, 156-58 (1965)]. See also PA. Stat. ANN. tit. 53, \$§ 10,707-08 (Supp. 1972).

23 See Babcock et al., supra note 22, at 70-75 [114 U. PA. L. REv. 143-52]. See also PA. Stat. ANn. tit. 53, \& 10,705 (Supp. 1972).

24 See Babcock et al., supra note 22, at 73-81 [114 U. PA. L. REv. 159-67]. See also PA. StaT. ANN. tit. 53, $\S \S 10,706,10,709-11$ (Supp. 1971).

25 The National Commission on Urban Problems recognized this relationship, stating: "[l]arge-scale projects, under unified planning and control, afford an important opportunity to create mixtures of housing types and to provide an environment in which people of varied income levels can live." DOUGLAS REPORT, supra note 5, at 247.

26 See Model Land Development Code 170-72 (Commentary on Art. 3, Pt. 1) (Tent. Draft No. 1, 1968) [hereinafter cited as MODEI CODE].

27 See, e.g., Eves v. Zoning Bd. of Adjustment, $401 \mathrm{~Pa} .211,164$ A.2d 7 (1960). See also Haar \& Hering, The Lower Gwynedd Township Case: Too Flexible Zoning or an Inflexible Judiciary?, 74 HARv. L. REv. 1552, 1557-66 (1961).

28 SZEA \& 3. See also 1 R. ANDERSON, supra note $11, \S 5.02$.

29 MODEL CODE, supra note 26, at 196 (Commentary on Art. 8).

$30 \mathrm{Id}$. 
the private developer makes his own decisions when, where, and to what extent to build. ${ }^{31}$ If the zoning ordinance permits a certain use, the township under end-state zoning theory may not tell a developer that delay until a subsequent year would be preferable ${ }^{32}$-it lacks discretion to limit development. A limited amount of discretion was available within the SZEA through the appeals mechanism, providing for review of arbitrary decisions by administrative officers or of denials of applications for a special exception or variance; ${ }^{33}$ however, these devices applied only under special circumstances. ${ }^{34}$

The principal means of discretionary decisionmaking (still ostensibly within the framework of end-state zoning) has been the amendment. The SZEA recognized that although the administrative agency was to be unwavering in its application of the zoning regulations, it might be necessary to change those regulations from time to time. The legislative body of the local municipality was, accordingly, granted amendment power. ${ }^{35}$ With amendments, as with any other municipal ordinance, ${ }^{36}$ courts are loath to inquire into the legislative motives. ${ }^{37}$ Shielded by the doctrine of separation of powers, township supervisors can escape end-state zoning's prohibition of discretionary decisionmaking, by zoning the township so as to render development infeasible. Development then takes place largely as a series of individual permissions, granting those who will build as the community sees fit, relief from the requirements no one is able to satisfy. ${ }^{38}$ Other techniques to

31 See, e.g., J. DeLafons, supra note 8, at 108.

32 Cf. Albrecht Realty Co. v. Town of New Castle, 8 Misc. 2d 255, 167 N.Y.S.2d 843 (Sup. Ct. 1957) (ceiling on building-permit issuance held invalid).

33 SZEA \& 7.

34 See, e.g., Mandelker, Delegation of Power and Function in Zoning Adninistration, 1963 WASE. U.L.Q. 60; Note, Administrative Discretion in Zoning, 82 HARv. L. REv. 668, 671-73 (1969); Note, Zoning Variances, 74 Harv. L. Rev. 1396 (1961). The abuse of this statutory grant of discretion is documented by three field studies. See Dukeminier \& Stapleton, The Zoning Board of Adjustment: A Study in Misrule, $50 \mathrm{KY}$. L.J. 273 (1962); Note, Zoning: Variance Administration in Alameda County, 50 CaIIF. L. REv. 101 (1962); Note, Zoning Variances and Exceptions: The Philadelphia Experience, 103 U. PA. L. REV. 516 (1955).

35 SZEA § 5. See generally 1 R. ANDERson, supra note 11, \$§ 4.25-.37.

36 See, e.g., 1 R. ANDERson, supra note 11, \$ 2.14. But see Haar \& Hering, supra note 27 , at $1565 \& \mathrm{n} .43$.

37 See, e.g., Bilbar Constr. Co. v. Board of Adjustment, 393 Pa. 62, 71-72, 141 A.2d 851, 856 (1958); accord, Village of Euclid v. Ambler Realty Co., 272 U.S. 365, 386-89 (1926). But see Johnson, Constitational Law and Community Planning, 20 LAw \& CONTENR. Prob. 199, 214-15 (1955).

38 See Krasnowiecki, The Basic System of Land Use Control: Legislative Preregulation v. Administrative Discretion, in THe New Zoning 3 (N. Marcus \& M. Groves eds. 1970). See, e.g., Valley View Village, Inc. v. Proffet, 221 F.2d 412 (6th Cir. 1955); Connor v. Town of Chanhassen, 249 Minn. 205, 81 N.W.2d 789 (1957). The technique does not always receive judicial approval, however. See Kimball v. Blanchard, 90 N.H. 298, 7 A.2d 394 (1939); Rockhill v. Chesterfield Twp., 23 N.J. 117, 128 A.2d 473 (1957); cf. Town of Hobart v. Collier, 3 Wis. 2d 182, 87 N.W.2d 868 (1958); State ex rel. Saveland P.H. Corp. v. Wieland, 269 Wis. 262, 69 N.W.2d 217 (1955). See generally Reno, Non-Euclidean Zoning: The Use of the Floating Zone, 23 Mo. L. REv. 105, 119-20 (1963); Reps, The Zoning of Undeveloped Areas, 3 SYRAcuSE L. REv. 292 (1952) ; Note, Non-Euclidean "Zoning": Its Theoretical Validity and Practical Desirability in Underdeveloped Areas, 30 U. CIN. L. REv. 297 (1961). 
force a developer to ask for a rezoning are large-lot zoning, ${ }^{39}$ the complete exclusion of apartments, ${ }^{40}$ and minimum-house-size requirements. ${ }^{41}$

Municipalities, it is no secret, employ such devices in the service of three major goals: negotiation with developers, regulation of development pace, and exclusion of "incompatible" people. ${ }^{42}$ Attraction of higher tax revenues and preservation of community rural appearance are sometimes raised as additional considerations prompting lowdensity zoning, ${ }^{43}$ but there is some doubt that either of these goals can be advanced thereby. ${ }^{44}$ The three purposes first mentioned, however, merit further discussion.

If it be one's purpose to provide low- and moderate-cost housing in the suburbs, the least controversial aim of large-lot zoning should be the township's bargaining with the developer. Few would hold illegitimate a community's interest in securing a pleasant neighborhood through high-quality new development, and the practice of reviewing a builder's reputation and bargaining with him for concessions is widely accepted..$^{45}$ In fact, the PUD approach encourages and legitimates this bargaining process ${ }^{46}$ - a process not objectionable, provided there is an impartial and open hearing and the township has the right to enforce promises made by the developer.

The use of low-density zoning to control the timing of develop-

39 Recent cases tend to invalidate large-lot zoning. See, e.g., Concord Twp. Appeal, $439 \mathrm{~Pa} .466,268$ A.2d 765 (1970); National Land \& Inv. Co. v. Easttown Twp. Bd. of Adjustment, $419 \mathrm{~Pa}$. 504, 215 A.2d 597 (1965); Board of County Supervisors v. Carper, 200 Va. 653, 107 S.E.2d 390 (1959). But cf., e.g., Senior v. Zoning Comm'n, 146 Conn. 531,153 A.2d 415 (1959), cert. denied, 363 U.S. 143 (1960). See also Note, Snob Zoning-A Look at the Economic and Social Impact of Low Density Zoning, 15 SxRACUSE L. Rev. 507, 508-11 (1964).

40 See Village of Euclid v. Ambler Realty Co., 272 U.S. 365 (1926). In recent years, however, such zoning has generally been invalidated. See, e.g., Molino v. Mayor \& Council, 116 N.J. Super. 195, 281 A.2d 401 (Law Div. 1971); Girsh Appeal, 437 Pa. 237, 263 A.2d 395 (1970). See also Symposium, Apartments in Suburbia: Local Respon sibility and Judicial Restraints, 59 Nw. U.L. REv. 344 (1964); Babcock \& Bosselman, Suburban Zoning and the Apartment Boom, 111 U. PA. L. REv. 1040 (1963). Siegan, Non-Zoning in Houston, $13 \mathrm{~J}$. LAw \& EcoN. 71, 128 (1970), observes:

The relative absence of restrictions on apartment development has allowed the market to satisfy the demand for apartments to a much greater degree than could occur under zoning controls. Rents are probably less as a consequence for most tenants. Among the beneficiaries are those tenants of lesser income levels who have been able to afford new apartments but probably would have been unable to do so if Houston had been zoned.

41 Compare Medinger Appeal, $377 \mathrm{~Pa} .217$, 104 A.2d 118 (1954), with Lionshead Lake, Inc. v. Wayne Twp., 10 N.J. 165, 89 A.2d 693 (1952), appeal dismissed, 344 U.S. 919 (1953). See also Haar, Zoning for Minimum Standards: The Wayne Township Case, 66 HARv. L. REv. 1051 (1953); Nolan \& Horack, How Small a House?-Zoning for Minimum Space Requirements, 67 HARv. L. Rev. 967 (1954).

42 See, e.g., Douglas RePort, supra note 5, at 214.

43 See Cutler, Legal and Illegal Methods for Controlling Community Growth on the Urban Fringe, 1961 WIs. L. REv. 370, 380-81. See also Becker, The Police Power and Minimun Lot Size Zoning-Part I: A Method of Analysis, 1969 WasH. U.L.Q. 263. $4 \pm$ See Note, Snob Zoning-A Look at the Economic and Social Impact of Low Density Zoning, 15 Syracuse L. Rev. 507, 514-18 (1964); of. ULI, TeCH. BULI. No. 32, The Effects of Large Lot Size in Residential Development 7-11 (1958).

45 See DOUGLas RePORT, supra note 5, at 216-17.

40 See generally Symposium, supra note 16. 
ment ${ }^{47}$ - to coordinate its rate and sequence ${ }^{48}$-is also understandable. The static end-state zoning of the SZEA ill-suits a dynamic world. But to say that a municipality has a legitimate interest in guiding its growth, is not to say that all such control is legitimate: it is important to distinguish the township that desires reasonably to time its development from the one that wants to exclude everyone save the very rich. Such distinctions are more readily made, just as bargaining with developers can more surely be kept untainted by the extension of special favors, when the sub rosa exercise of discretion is rejected in favor of open, fair procedures administered by bodies sensitive to the development-timing needs of the larger community.

Finally, the use of low-density zoning to exclude people considered undesirable by communities is an abuse of the amendment process hardly to be countenanced. Direct and open exclusion on the basis of race would be quickly invalidated..$^{40}$ Likewise, an ordinance clearly prohibiting low-income families from living in a municipality would stand little chance of success. However, these are the easy cases. ${ }^{50}$ Zoning has its authority in the police power, and an ordinance whose reasonable relation to the public health, safety, morals, or general welfare is at least "fairly debatable" will be accorded judicial deference. Ordinances directly excluding blacks or the poor do not even qualify as "fairly debatable"; however, one need not strain to hold reasonable, or at the very least "fairly debatable," a decision by a municipality to exclude small houses, small-acreage lots, or apartments. The effect of such land-use regulations is to raise the price of land, and therefore the price of a dwelling unit, beyond the reach of low-income and even moderate-income families, in many cases.

It is in making possible the subtle form of discrimination lastdiscussed that American zoning law is most susceptible of indictment. Only dramatic remedial action will eliminate this possibility.

\section{Regionalism-Role and Reality}

Immediate control over land-use decisions probably must be left in the hands of local governments. ${ }^{51}$ The right to participate in such

47 See DOUGIAS REPORT, supra note 5, at 214.

48 See Fagin, Regulating the Timing of Urban Development, 20 Law \& ContenrP. PROB. 298 (1955).

49 See Buchanan v. Warley, 245 U.S. 60 (1917); accord, In re Lee Sing, 43 F. 359 (N.D. Cal. 1890); cf. Yick Wo v. Hopkins, 118 U.S. 356 (1886). See also Lefcoe, The Public Housing Referendum Case, Zoning, and the Supreme Court, 59 CALIF. L. Rev. 1384, 1405-09 (1971).

$50 \mathrm{Few}$ cases decide whether a community can directly exclude poor families by setting a minimum construction cost. See, e.g., County Comm'rs v. Ward, $186 \mathrm{Md}$. 330, 336, 340, 46 A.2d 684, 686, 688 (1946). See also Williams, Planning Law and the Supreme Court:-II, 13 Zontng Digest 97, 108-10 (1961); Williams, Planning Law and Democratic Living, 20 LAW \& ConTeMT. ProB. 317, 343-46 (1955). But see Sager, Tight Little Islands: Exclusionary Zoning, Equal Protection, and the Indigent, 21 STAN. L. Rev. 767, 790-93 (1969).

o1 See R. BABCOCK, supra note 13 , at 153. Of course, one more readily accepts such a situation, if local governments are large enough, powerful enough, and well-informed 
decisions makes democracy more meaningful and more effective. ${ }^{52}$ This accounts in part, no doubt, for the demands for power over their communities made by urban neighborhood groups. ${ }^{53}$ At the same time, attacks frequently are leveled against the parochialism of suburban decisionmaking. ${ }^{54}$ The values of decentralization must be balanced against the importance of pressing regional and national needs. ${ }^{55}$ Suburban municipalities have been most effective in thwarting the attempts of large numbers of city dwellers to relocate in the suburbs.$^{56}$ In light of our history and tradition, it would be politically naive to believe that control over land use could be wrested altogether from suburban municipalities, but it is not unrealistic, at a minimum, to require that decisions be made in light of regional needs. ${ }^{57}$ This Comment will urge a more structured consideration of regional concerns.

\section{Judicial Inadequacies}

Court decisions have not brought about any substantial increase in the construction of low- and moderate-income housing in the suburbs. Four primary obstacles prevent the courts from responding effectively to the problems posed by exclusionary zoning: (1) strong precedent to the effect that only the avowed purpose, not the effect nor the motive however fairly imputed, of zoning ordinances should be reviewed, (2) traditional limitations on standing, (3) the shortcomings of the available substantive legal theories, and (4) the narrow range of remedies available.

\section{Early Limits on the Scope of Judicial Inquiry}

At issue in Village of Euclid v. Ambler Realty Co. ${ }^{58}$ was the constitutionality of a zoning ordinance creating an entirely residential district, which the plaintiff alleged denied him the use of his land for

enough to deal competently with problems. Cf. Dovglas Report, supra note 5, at 236-39. See also Housing Act of 1949 \& 2, 42 U.S.C. § 1441 (1970),

52 Cf. Michelman, The Advent of a Right to Housing: A Current Appraisal, 5 Harv. Civ, Rights-Civ. LiB. L. Rev. 207, 225-26 (1970).

53 See generally David \& Lewis, Citizen Participation, 20 J. Housnsg 472 (1963);

Note, Tenant Unions: Collective Bargaining and the Low-Income Tenant, 77 YALE L.J. 1368 (1968).

54 See, e.g., R. Vernon, The Myth and Reality of OUR Urban Problems 61-67 (1966); Babcock \& Bosselman, supra note 40.

55 See Babcock \& Bosselman, Citizen Participation: A Suburban Suggestion for the Central City, 32 LAw \& Contemp. Pros. 220, 222 (1967).

56 See Dodglas Report, supra note 5, at 18-20. See also Vickers v. Township Comm., 37 N.J. 232, 252-70, 181 A.2d 129, 140-50 (1962) (Hall, J., dissenting), appeal dismissed, 371 U.S. 233 (1963).

57 See R, BABCOCK, sulpra note 13, at 153. Cf. DotgLAS REPORT, supra note 5, at 236:

[t]he range of local actions must be effectively limited by the States and the

Federal Government, both to assure fair treatment of property owners and minorities in each locality and to assure that local decisions will not place unfair, uneconomic, or unrealistic burdens on people who live outside a given local jurisdiction.

58272 U.S. 365 (1926). 
commercial, industrial, or apartment uses, and commensurately diminished the value of his land. The lower court ${ }^{59}$ found the ordinance unconstitutionally deprived plaintiff of his property without due process of law. Noting that it served to further "class tendencies," District Judge Westenhaver wrote:

The plain truth is that the true object of the ordinance in question is to place all the property in an undeveloped area of 16 square miles in a strait-jacket. The purpose to be accomplished is really to regulate the mode of living of persons who may hereafter inhabit it. In the last analysis, the result to be accomplished is to classify the population and segregate them according to their income or situation in life. ${ }^{60}$

But this scrutiny of the unworthy motive was limited to the lowercourt opinion; the Supreme Court confined its inquiry to whether reasonable justifications could be advanced for the exclusion of apartment houses. ${ }^{61}$ The Court concluded that apartments "come very near to being nuisances, ${ }^{, 62}$ and held that under the circumstances the zoning was a reasonable exercise of the police power. The issue of exclusionary impact had not been presented to the Court by plaintiff, but municipalities could nevertheless feel safe in zoning to exclude low-income families, so long as the overt purposes of their ordinance were at least "fairly debatable." It is obvious how ineffectual judicial review of exclusionary zoning must be, under so narrow a scope of inquiry. Despite the absence of leadership from the highest court, ${ }^{64}$ there is growing judicial support for the proposition that a suburban municipality may not utilize restrictive zoning to achieve the effect of excluding low-income families. ${ }^{65}$ However, the impact of these decisions is limited by the other constraints under discussion here.

\section{Limitations on Standing}

One reason why courts have made so little progress towards solving exclusionary-zoning problems is that standing is granted only to select interest groups. As a result, classes of plaintiffs representing vital viewpoints are denied a judicial hearing.

The SZFA makes no explicit provision for standing to appeal decisions made by municipal legislatures; ${ }^{\text {Bo }}$ the courts have filled this

59297 F. 307 (N.D. Qhio 1924).

$60 \mathrm{Id}$. at 316.

01272 U.S. at 394.

62 Id. at 395.

63 Id. at 388.

64 The last zoning case heard by the Supreme Court was Nectow v. City of Cambridge, 277 U.S. 183 (1928), a fact suggesting tacit approval of subsequent lowercourt decisions. text.

${ }^{85}$ See noțes 38-41 supra \& accompanying text; cf. notes 49-50 supra \& accompanying

${ }^{66}$ See also Krașnowiecki, supra note 18 , at 56. 
legislative gap by borrowing the SZEA standing requirements for appeals of adjustment-board decisions. ${ }^{67}$

The question of standing frequently arises in the context of a dispute over a developer's zoning-amendment petition. An amendment might be sought when a developer feels an available tract of land is zoned at a classification prohibitive of profitable development. The dispute could arise whether the local legislature grants or denies the amendment. If the amendment is denied, the developer usually has standing to bring an action against the municipality. ${ }^{68}$ If the amendment is granted, neighboring residents usually have standing to protest. $^{69}$ Nonresidents, however, have access to courts as parties to a zoning dispute only in limited circumstances. ${ }^{70}$

Thus, the courtroom doors are closed to those plaintiffs most harmed, perhaps, by the amendment's denial and most likely to raise regional concerns. Neighboring property owners are likely to oppose all new development not calculated to attract people of their own income brackets. ${ }^{71}$ And, although the developer may challenge the community's zoning, it will most likely be for the purpose of building luxury apartments, not low- and moderate-income housing. ${ }^{72}$

\section{Available Legal Theories}

None of three theories commonly resorted to $^{73}$ affords significant likelihood of judicial overturning of exclusionary zoning. Equal protection doctrine has not been, nor does it appear likely to be, stretched so far. Due-process or breach-of-affirmative-duty theories, though they may in some instances prevail, are as yet too undeveloped, or in any event not sufficiently predictable, to justify reliance thereupon.

67 SZEA § 7. See generally Ayer, The Primitive Law of Standing in Land Use Disputes: Some Notes from a Dark Continent, 55 IowA L. Rev. 344 (1969). See also Foss, Interested Third Parties in Zoning, 12 U. FLA. L. REv. 16 (1959); Comment, The "Aggrieved Person" Requirement in Zoning, 8 WM. \& MARY L. REV. 294 (1967); Comment, Standing to Appeal Zoning Determinations: The "Aggrieved Person" Requirement, 64 MTCH. L. REv. 1070 (1966).

68 Cf. Krasnowiecki, Zoning Litigation and the New Pennsylvania Procedures, 120 U. PA. L. REv. 1029, 1054-57 (1972).

69 See, e.g., Wakefield v. Kraft, 202 Md. 136, 142-43, 96 A.2d 27, 29-30 (1953). Cf. 1 R. ANDERSON, supra note 11 , $\S 8$ 5.05-.06.

70 See Hamelin v. Zoning Bd., 19 Conn. Supp. 445, 117 A.2d 86 (C.P. New Haven 1955) ; Koppel v. City of Fairway, $189 \mathrm{Kan} .710$, 371 P.2d 113 (1962); Al Walker, Inc. v. Borough of Stanhope, 23 N.J. 657, 130 A.2d 372 (1957); Note, Extending Standing to Nonresidents-A Response to the Exclusionary Effects of Zoning Fragmentation, 24 VAND. I. REv. 341 (1971). See also Comment, Standing to Challenge Exclusiondry Local Zoning Decisions: Restricted Access to State Courts and the Alternative Federal Forum, 22 SyRACUSE L. Rev. 598 (1971). But cf. Note, 38 N.Y.U.L. Rev. 161 (1963).

71 See R. BABCock, supra note 13, at 31-32, 48-49.

72 See, e.g., Strong, Girsh and Kit-Mar: An Unlikely Route to Equal Opportunity in Housing, 22 ZONING DIGEST 100a (1970).

73 See generally Marcus, Exchusionary Zoning: The Need for a Regional Planning Context, 16 N.Y.L.F. 732 (1970); Williams \& Norman, Exclusionary Land Use Controls: The Case of North-Eastern New Jersey, 22 SYRAcuse L. Rev. 475, 498-502 (1971); Comment, A Survey of the Judicial Responses to Exclusionary Zoning, 22 SYRACuSE L. REV. 537 (1971). 


\section{a. Equal Protection}

The proposition that low-density zoning denies nonresident poor families the equal protection of the law has been urged by several commentators, ${ }^{74}$ although no court has yet reached this conclusion. ${ }^{75}$ The commentators argue that low-density zoning increases the cost of each dwelling unit in a suburban community to the point where poor and moderate-income families are denied entry. The result is that persons are classified, as respects their access to suburban land, in a manner without valid countervailing justification. Such an invidious classification, the argument runs, unfairly discriminates against the poor, and by implication against blacks and other minorities, and therefore constitutes a denial of equal protection. ${ }^{78}$

The commentators distinguish between the old equal protection and the new, more active, equal protection. The traditional view is that government must merely be rational in its distribution of benefits and burdens. The "new equal protection" calls for a more searching judicial balancing of the public interest advanced against the private loss inflicted as a result of any legislation, even legislation appearing neutral on its face, whenever the line drawn involves a "suspect classification" or a "fundamental interest."

In Lindsey v. Normet the Supreme Court refused to hold housing to be a fundamental interest, ${ }^{78}$ despite earlier concern about the right to equal housing opportunity. ${ }^{79}$ The case involved, among other things, an equal protection challenge to Oregon's judicial procedure requiring an early trial and limiting litigable issues for the eviction of tenants for nonpayment of rent. The rationale rejecting the attack went beyond the facts and demonstrated an unwillingness to extend any further the new equal protection. ${ }^{80}$

We do not denigrate the importance of decent, safe, and sanitary housing. But the Constitution does not provide judicial remedies for every social and economic ill. We are unable to perceive in that document any constitutional guarantee of

74 See Sager, supra note 50. See also Aloi \& Goldberg, Racial and Economic Exclusionary Zoning: The Beginning of the End?, in 1971 URBAN IAw ANN. 9; Michelman, Forword: On Protecting the Poor Through the Fourteenth Amendment, 83 HaRv. L. REv. 7 (1969); Note, Exclusionary Zoning and Equal Protection, 84 HARV. L. REv. 1645 (1971); Note, Snob Zoning: Must a Man's Home Be a Castle?, 69 MicH. L. Rev. 339 (1970); Note, The Constitutionality of Local Zoning, 79 YaLE L.J. 896 (1970).

.75 Cf. Concord Twp. Appeal, 439 Pa. 466, 474 n.6, 263 A.2d 395, 399 n.6 (1970).

76 Aloi \& Goldberg, supra note 74, at 12-17.

77 See, e.g., Note, Exclusionary Zoning and Equal Protection, 84 Harv. L. Rev. $1645,1650-53$ (1971). Cf. Lefcoe, supra note 49 , at 1425-28.

78405 U.S. 56, 73-74 (1972). Cf. James v. Valtierra, 402 U.S. 137 (1971) (implicitly balancing the interest in decent housing against the right of residents of a community to control their environment, in favor of the latter).

79 See note 3 supra \& accompanying text.

so Cf. Gunther, Forword: In Search of Evolving Doctrine on a Changing Court: A Model for a Newer Equal Protection, 86 HARv. L. REv. 1 (1972). 
access to dwellings of a particular quality or any recognition of the right of a tenant to occupy the real property of his landlord beyond the term of his lease, without the payment of rent or otherwise contrary to the terms of the relevant agreement. Absent constitutional mandate, the assurance of adequate housing and the definition of landlord-tenant relationships are legislative, not judicial, functions. ${ }^{81}$

Institutional, as well as doctrinal, difficulties would follow, were the Court to hold that large-acreage zoning might deny equal protection. Since, as seems not unreasonable, such zoning might be legitimate at times, ${ }^{82}$ a heavy burden would be placed on the lower federal courts to pick their way through various ordinances, weighing each on its merits-a substantive-land-use-planning involvement that state courts have been avoiding for years. ${ }^{83}$

Equal protection doctrine, then, cannot be relied upon to equip the courts with any solution to exclusionary-zoning problems.

\section{b. Due Process}

The substantive-due-process theory, under which it is urged that exclusionary zoning does not permit property owners to use their land reasonably, involves a tension between the local municipality and the developer. ${ }^{84}$ The municipality's desire to maintain an attractive environment must be balanced against the profits which a developer could possibly realize. In the past, courts have tended to uphold the ordinances, ruling that large-acreage zoning is reasonably related to legitimate legislative goals-preserving open space, avoiding a drain on municipal services, or maintaining the existing property values. ${ }^{85}$ Recent decisions of the Pennsylvania Supreme Court ${ }^{86}$ have demonstrated a receptiveness to due-process claims, but due-process theory nevertheless can not be relied upon to resolve the concerns raised in this Comment. There is no necessary identity of interest between the developer (the only participant in such disputes as to whom the lostprofits claim so important to substantive-due-process arguments under discussion here makes sense) and excluded nonresidents. ${ }^{87}$

81405 U.S. at 74.

82 See notes 44-48 supra \& accompanying text.

83 See R. BABCock, supra note 13, at 104-05.

84 See, e.g., Sager, supra note 50, at 784.

85 See Comment, supra note 73, at 538-62.

86 See, e.g., National Land \& Inv. Co. v. Easttown Twp. Bd. of Adjustment, $419 \mathrm{~Pa}$. $504,532,215$ A.2d 597, 612 (1965) (overturning four-acre residental zoning): "A zoning ordinance whose primary purpose is to prevent the entrance of newcomers in order to avoid future burdens, economic and otherwise, upon the administration of public services and facilities can not be held valid." See also Concord Twp. Appeal, 439 Pa. 466, 268 A.2d 765 (1970). Similar stirrings have taken place in Virginia. See Board of Supervisors v. Carper, 200 Va. 653 , 107 S.E.2d 390 (1959).

87 See, e.g., Williams \& Norman, supra note 73, at 498-502; cf. Strong, supra note 72. See generally Williams, Planning Law and the Supreme Court: $\dot{I}, 13$ ZoNang DIGEST 57 (1961). 


\section{c. Affirmative Duty}

The third, and perhaps most promising, theory is that municipalities have an affirmative duty to plan for regional needs-and, particularly, an obligation to accommodate low- and moderate-income families desiring to move into them. Recent New Jersey decisions suggest such an affirmative duty may be held to flow from some notunusual statutory provisions. In DeSimone v. Greater Englewood Housing Corp. No. $1{ }^{88}$ the Supreme Court of New Jersey upheld the granting of a use variance for the construction of a low- and moderateincome housing project. Under New Jersey law, a variance could only be issued if there existed "special reasons," defined by the court as including the promotion of "health, morals or general welfare." 89 The court held that the attempt to relieve the shortage of low- and moderate-income housing fell within the definition of the general welfare, and therefore was a "special reason" justifying a variance. In Oakwood at Madison, Inc. v. Torenship of Madison, ${ }^{90}$ plaintiffs, two developers and six nonresidents, challenged the constitutionality of low-density zoning on the theory that it ignored regional housing needs. The superior court found the ordinance was invalid, because not in compliance with the mandate to zone for the "general welfare":

The general welfare does not stop at the municipal boundary. Large areas of vacant and developable land should not be zoned, as Madison Township has, into such minimum lot sizes and with such other restrictions that regional as well as local housing needs are shunted aside..$^{91}$

Affirmative-duty theories, while interesting, yet represent an undeveloped area of law, and if relied upon, may prove unsuccessful.

\section{Lack of a Satisfactory Remedy}

Even if any standing hurdles are overcome and an exclusionary zoning ordinance is declared invalid, there is no assurance that lowand moderate-income housing will be built in that municipality. First, a court will not order a municipal officer to issue a building permit unless it is clear on the record that all the requirements necessary for one have been met. Generally the court does not have the expertise to decide, on less than a clear showing, if a particular plan meets even the basic minimum standards for safe or livable housing. Second, unless the land immediately in question is already zoned for the developer's desired use, the township can frustrate his expectations by making

8856 N.J. 428, 267 A.2d 31 (1970). Cf. Molino v. Mayor \& Council, 116 N.J. Super. 195, 281 A.2d 401 (Law Div. 1971).

8956 N.J. at 440,267 A.2d at 37.

80117 N.J. Super. 11, 283 A.2d 353 (Law Div. 1971). Cf. Borough of Creskill v. Borough of Dumont, 15 N.J. 238, 104 A.2d 441 (1954) ("comprehensive plan" must consider regional interests).

01117 N.J. Super. at 20-21, 283 A.2d at 358. 
"available" other land for the use judicially called for. ${ }^{92}$ Finally, a developer must be willing and able to build-this decision remains in private hands.

\section{Summary}

The courts, then, are powerless. Powerless to force low-income housing to be built. Powerless to bring conventional theories to bear with any palpable impact on the problem. Powerless even to hear many a case in this area, given the limitations of standing. And powerless, within the Euclid tradition, to focus on discriminatory effect or motive, given a rational basis for a zoning enactment. Solution to our zoning and housing problems, then, must be sought elsewhere.

\section{APPROACHING A Solution}

\section{A. The Proposal}

A new statutory scheme for zoning should be established, embracing a two-part quota system and a statewide reviewing agency, possibly with regional branches. The scheme would be so designed that municipalities would set quotas with an eye to both regional needs and the suburban communities' legitimate interests. In effect, low-density zoning already results in a quota system protective of the latter interests; this proposal, therefore, is revolutionary only, if at all, in its call for such quotas' being endorsed by state legislatures and being made to answer, not frustrate, regional needs.

A township would discharge its obligation to accept its fair share of the regional demand for low- and moderate-income housing either by accepting public housing or by requiring, through the zoning ordinance, that private developers include, in PUDs or other multi-family housing projects, at least stipulated percentages of low- and moderateincome housing units. ${ }^{93}$ In practice, many developers will be able, through the Department of Housing and Urban Development, to obtain federal subsidies for such public-interest housing. Of course, HUD's processing of grant-applications is notoriously slow, its cost-limits are low, and the absolute quantity of money available is limited. ${ }^{94}$ However, a developer's inability to obtain federal subsidy need not, and

92 For the aftermath of Girsh Appeal, $437 \mathrm{~Pa} .237,263$ A.2d 395 (1970), see Krasnowiecki, supra note 68 , at 1080-82.

93 Fairfax County, Virginia, requires all developers proposing to build more than 50 units in PUD or multi-family-housing zones are required to reserve at least $15 \%$ of the units for low- and middle-income housing, including at least $6 \%$ for low-income housing. See Fatrfax COUNTY, VA., CODE, Ch. 30 (1961). Although the ordinance was immediately invalidated, primarily on the ground that the county supervisors had exceeded their statutory authority, an appeal is pending. DeGroff Enterprises, Inc. v. Board of Supervisors, Law No. 25,609 (Cir. Ct. Fairfax Co., Nov. 11, 1971), writ granted, No. 8118, Sup. Ct. Va., Oct. 24, 1972.

94 See Lefcoe, supra note 49, at 1445-47. See also Low and Moderate Income Housing: Zoning Ordinance Changes 4-8, June 29, 1971 (unpublished report by Fairfax County Supervisors' Committee appointed June 16, 1971), copy on file in Biddle Law Library, Univ. of Pa. [hereinafter cited as Committee Report]. 
should not, entail waiver of the unit-percentage requirement.95 An innovative use of housing-density bonuses, especially for large-scale developments, could easily compensate developers for any financial burdens occasioned by the requirement to construct low-income housing. ${ }^{96}$ Of still greater financial benefit to the developer would be the allowance of additional square footage for commercial uses; assuming purchase of his land was effected at a price not reflecting such uses, he would receive an indirect subsidy. In the case of smaller developments, with respect to which density bonuses or increased commercial development might be unacceptable to the township, other subdivision exactions could be waived. ${ }^{97}$ In sum, the provision of low- and moderateincome housing need by no means be dependent upon federal funding.

To encourage willing adoption of such a quota requirement by local governments, and to make operation under the scheme fair among localities in the same region, a second quota - a growth quota-would be authorized. Thus, the system would relieve anxieties that a community, by its receptiveness to low-income housing, might accommodate more than its share.

In preparing the growth quota, the township would be required to determine what portion of the regional demand for housing, of all types and price ranges, is its "fair share." Relevant considerations in gauging its capacity for growth will include its ecological and geographical features, its sewers, streets, schools, and commercial facilities, and its prospects for financing capital improvements for these services. On the basis of such information, the township would project a reasonable rate of population growth for the next five-year period. For each year thereafter, each community would be required to prepare an annual planning report, ${ }^{98}$ containing, in addition to capacity information as in the original report, sections relating to the land-use and development decisions made during the year, the degree of success achieved by the community in reaching its housing goals, and any proposed modifications to the plan. The community would thus be forced to engage in a constant planning effort.

Flexible development should be the keynote. If a community permits development so that its five-year quota is fulfilled in the period's first twelve months, it would then be allowed to deny permission to build for the next four. If essential facilities must be constructed before a township can withstand further growth, development

95 The Fairfax County scheme provides just such a waiver. See note 93 supra.

${ }^{96}$ See, e.g., Michelman, Property, Utility, and Fairness: Comments on the Ethical Foundations of "Just Compensation" Law, 80 HARv. L. REv. 1165, 1218 (1967). Density bonuses are provided by the Fairfax County ordinance, see note 93 supra, at the rate of one additional high-income unit for each two low- or moderate-income units.

${ }^{97}$ Cf. Committee Report, supra note 94 , at 9.

${ }^{98}$ Cf. Krasnowiecki, Model Land Use and Development Planning Code $\$ \S 209,303$ \& Notes, in Mlaryland Planning \& Zoning Law Study Comm's, Finat Report: LegisLATTVE RECOMTMENDATTONS 107-12, 113-16 (1969). 
might fairly be postponed until these facilities are built-provided its full five-year quota is nevertheless met. Should it become apparent only at the end of five years that a community has failed to meet its quota, then a new quota will be imposed upon the township to recoup the deficit. But if a community fails to reach its goal not through municipal foot-dragging, but rather because of lack of home-buyer and developer interest, then it may be excused from making up the deficit.

The fair administration of such a flexibly-applied system will require a statewide reviewing agency, staffed by planners as well as by lawyers. The agency would supply municipalities with needed statistical information, would pass upon their quotas (with regional interests considered paramount over local concerns), and-aided by their annual filings-would monitor their performance and commitment to the goal of developing low- and moderate-income housing. ${ }^{99}$ So broad would be the state agency's power to review all decisions affecting the application of low- and moderate-income housing quotas, ${ }^{100}$ that no appeal to the courts would be allowed until the agency had considered the matter at issue. ${ }^{101}$ When passing upon such local actions, the reviewing agency would be empowered to approve (with or without modification) or to veto the action; ${ }^{102}$ in short, "[i]t should be empowered to substitute its decisions in adjudicatory matters for those of the locality."103

Traditional judicial and statutory rules limiting when, and by whom, suits may be brought, should be abolished. In order to hasten certainty with regard to land-use actions, plaintiffs should be required to bring their challenges within thirty days, ${ }^{104}$ and challenges should be allowed whenever "there is no reasonable possibility that the restriction can be avoided"105 by recourse directly to the local body. Standing should be broadly defined, so that the state reviewing agency can

${ }^{99} \mathrm{Cf}$. id. The need for a state agency with broad powers to plan and administer land-use controls has frequently been noted by commentators. See Haar, Regionalism and Realism in Land-Use Planning, 105 U. PA. L. Rev. 515 (1957). See also Becker, Municipal Boundaries and Zoning: Controlling Regional Land Development, 1966 WASH. U.L.Q. 1; Bowe, Regional Planning Versus Decentralized Land-Use Controls-Zoning for the Megalopolis, 18 DEPAUL L. REv. 144 (1968); Clark, The Extension of Political and Legal Order to the Metropolitan Area Community, 111 U. PA. L. Rev 855 (1963); Comment, Recent Trends in State Planning Legislation: A Selective Survey, 16 Burraco L. Rev. 801 (1967); Note, The Regional Approach to Planning, 50 IowA L. REv. 582 (1965); Note, Regional Impact of Zoning: A Suggested Approach, 114 U. PA. L. REV. 1251 (1966). $\S 7-205$.

100 See, e.g., Dodglas RePORT, supra note 5, at 239-40; MODEL CODE, supra note 26,

101 See, e.g., DodgLAS REPORT, supra note 5, at 240. In order to promote efficient and optimally-informed operation of the state agency, its subdivision into regional (metropolitan-area) authorities may appear desirable. Cf., e.g., VT. STAT. ANN. tit. 10, \$\$ 6026(a), 6083, 6086 (Supp. 1972) ; HawaII REv. Laws \$\$ 205-3 et seq. (Supp. 1971). See also Denney, State Zoning in Hawaiz: The State Land-Use Law, 18 ZonING DrGest 89 (1966). 102 Cf. MODEL CoDE, supra note 26, $\S \S 401(5), 402(5)(b)$ \& Commentary.

103 DoUGLAs REPORT, supra note 5 , at 240.

104 Cf. MODEL CODE, supra note 26, §§ 401(2), 402(2) \& Commentary.

$105 I d . \S 402(4)$. 
consider all relevant interests. Standing, certainly, should be retained by the developer and by neighboring property owners, but should also be held to extend to neighboring municipalities and nonresidents and to the staff of the state reviewing agency-groups representing vital interests in land-use controversies over low- and moderate-income housing. The inner-city community ought to have the opportunity to protest, if a suburb does not responsibly set its quotas. Suburban municipalities, similarly, should be able to assert that another community is not assuming its "fair share" of regional new-housing needs, which fall more heavily, as a result, on the cooperating municipalities.

Finally, within the framework here proposed, the reviewing agency would itself remain subordinate ultimately to the state legislature, which would articulate broad policies and establish statewide housing goals with special emphasis on low- and moderate-income housing. To aid the legislature in establishing the statewide quota, the agency would gather information on the condition, capacity, and location of present low- and moderate-income housing, of public utilities, and of other relevant facilities, ${ }^{106}$ and would determine the demand for low- and moderate-income housing. The statewide housing quota having been established by the legislature, the reviewing agency would be empowered to adopt rules and regulations to ensure that local decisions are consistent with state goals.

The framework proposed is, to be sure, much more elaborate than that producing zoning decisions today. But given the need for external checks on local government and for regional accountability, and given also the inherently local nature of land-use planning, it is unlikely that one could confidently entrust the accomplishment of so important a goal as the provision of better housing to a lesser administrative scheme.

\section{B. Potential Problems}

Although there may be some concern that either or both quotas constitute takings of the developer's property, for which just compensation must be paid, or that the quota system may deny equal protection to some developers, neither theory poses a serious constitutional threat to the proposal here advanced. The low-income housing requirement is similar in effect to more conventional subdivision exactions, such as those for streets, schools, sewers, and parks, which have been generally upheld when found reasonable by a judicially-determined standard. ${ }^{107}$ Even if the quota can be characterized as a "taking," it will be compensated for in kind by the density and commercial bonuses. ${ }^{108}$

108 See Haar, supra note 99, at 518-20.

107 See Heyman \& Gilhool, The Constitutionality of Imposing Increased Community Costs on New Suburban Residents Through Subdivision Exactions, 73 YaIE L.J. 1119 (1964).

108 See, e.g., Michelman, supra note 96, at 1218. 
The growth quota should not be considered a taking because the developer, although prevented from building because a goal has been reached, has not had his speculative profits taken altogether, but rather has simply had their receipt postponed. ${ }^{109}$

Finally, a developer might raise an equal-protection question by claiming that there is no real difference between his proposed project and one already allowed by the legislature. The fact that he sought a building permit second, he would argue, does not justify denial of his request. When an economic regulation is under attack, ${ }^{110}$ however, "[a] statutory discrimination will not be set aside if any state of facts reasonably may be conceived to justify it."111 A court will only set aside legislation that is "invidious" or "arbitrary." opment timing has not in the past been viewed as a valid discriminating factor in zoning, this may be explained as a result of traditional endstate, anti-discretionary zoning theory-a theory that grew increasingly out of line with the reality of unrestrained, covert discretionary decisionmaking by the local legislatures. The proposed legislation would legitimate the use of discretion and of a timing mechanism (the growth quota), in order to achieve a more rational and equitable system of land-use controls. To permit discrimination on a "first-come" basis is hardly invidious, since the class of those discriminated against is impossible to predict in advance, is not closed, and will be constantly shifting.

\section{Prospects}

Perhaps the most significant concerns one might have with respect to the quota approach are whether it would be accepted and whether it would work effectively. At least one suburban county has in fact adopted a very similar scheme. Fairfax County, Virginia, did so, ${ }^{113}$ apparently because it believed there was a need for low- and moderateincome housing nearer the factories and plants which have been relocating in the suburbs. ${ }^{114}$ Even though the invalidation of Fairfax's scheme may be reversed on appeal, time would be needed to determine to what extent it will succeed, especially absent a regional authority.

Regional cooperation in the distribution of low- and moderateincome housing has seen some success. In Ohio, the Miami Valley Regional Planning Commission convinced suburban municipalities to

109 Cf. Golden v. Planning Bd., 30 N.Y.2d 359, 285 N.E.2d 291, 138 N.Y.S.2d 334 (1972); DougLas REPORT, supra note 5, at $245-46$ (delays occasioned through proposed "holding zones" thought not so restrictive as to constitute takings).

110 See Morey v. Doud, 354 U.S. 457, 465-66 (1957).

111 McGowan v. Maryland, 366 U.S. 420, 426 (1961).

112 Ferguson v. Skrupa, 372 U.S. 726, 732 (1963); Williamson v. Lee Optical Co., 348 U.S. 483,489 (1955).

113 For details of the Fairfax scheme see notes 93-96 supra.

114 See Lefcoe, supra note 49, at 1448-49. 
accept such housing. ${ }^{115}$ Although some communities have retreated from their earlier enthusiasm, the program can claim to have been rather effective. In January 1969, neither public housing nor FHAassisted housing projects could be found outside of Dayton. Within four years, 1354 units were built or under construction outside Dayton, and 2723 were proposed to be constructed by agreement. ${ }^{116}$ The largest part of the advance is as yet only a promise; some doubt that all the proposed housing will materialize. The attitude in Dayton is optimistic, however, and the feeling exists that despite its difficulties the program can work. ${ }^{117}$

Although the assumption that suburbs will violently oppose any diminution of their power is probably still warranted in theory, ${ }^{118}$ it is not unrealistic to expect they could consider it in their own selfinterest to endorse the proposal recommended here. Suburbs would be enabled, through the five-year growth quotas, to rely on orderly development. Exclusionary zoning techniques may succeed in delaying, but can not succeed in scheduling, growth. They are also somewhat unpredictable, due to the vagaries of litigation, and do not permit such free bargaining with developers as has been proposed. Similarly, the low- and moderate-income housing quota may appear more attractive than the risk of unrestrained development of low- and moderate-income housing after a costly court battle. State courts are with increasing frequency invalidating zoning which has the effect of excluding lowand moderate-income families, ${ }^{119}$ and the fear of taking more than its "fair share" of such families may induce many a community to back the quota plan. Finally, suburban municipalities may reckon regional control of some sort to be inevitable, and would wisely prefer a scheme seeking maximum local control (consistent with regional needs) to eventual regional control or perhaps even metropolitan government.

At the state level, adoption of a regulatory scheme such as that described above would not be unprecedented. Both the Massachusetts anti-snob zoning legislation, ${ }^{120}$ requiring every suburban municipality to make available to non-profit or limited-profit housing sponsors at least 0.3 percent of its vacant land each year for a five-year period, and

115 See Miami Valley Regional Planning Commission, A Housing Plan for the Miami Valley Region: A Summary Including Housing Policies as Amended Dec. 1, 1971; Bertsch \& Shafor, A Regional Housing Plan: The Miami Valley Regional Planning Commission Experience, 1 PIANNER's NOIEBOOK 1 (1971) (reprint); Craig, The Dayton Area's "Fair Share" Housing Plan, CITY, Jan./Feb. 1972, at 6-7 (reprint) (author's numbering).

${ }^{116}$ Miami Valley Regional Planning Comm'n, Housing Program Progress Report, Oct. 1972, copy on file at Biddle Law Library, Univ. of Pa.

117 Craig, supra note 115, at 7.

118 See Bowe, supra note 99, at 164; Haar, supra note 99 , at 535.

110 See notes 38-41, 49-50, 86 supra \& accompanying text.

120 Mass. ANN. Laws ch. 40B, \$§ 20-23 (Supp. 1971). See Legislative Developments, Snob Zoning: Developments in Massachusetts and New Jersey, 7 HaRv. J. Legis. 246 (1970). 
New York's Urban Development Corporation legislation, ${ }^{121}$ intended to prevent local governments from blocking housing developments found to be in the regional interest, provide analogously for the overturning of local decisions insensitive to larger needs. Similarity may also be found in environmental-protection schemes, such as that of Vermont, ${ }^{122}$ providing for regional and statewide supervision of land utilization.

In sum, the outlook is as promising as the opportunities. Granted, the opening of America's suburbs is an ambitious goal, and lawyers by nature are distrustful of pat solutions. But the difficulties that may present themselves should prompt us to redouble, not abandon, our efforts.

121 N.Y. UnCONSOL. Laws $\$ 6251$ et seq. (McKinney Supp. 1970).

122 VT. Stat. AnN. tit. 10, § 6001 et seq. (Supp. 1972). 